\title{
SUSTAINABILITY AS A SUCCESS FACTOR IN GLOBAL OPERATIONS: A SURVEY OF CAR MANUFACTURING SUPPLY CHAINS
} Anhembi Morumbi University, Brazil.

E-mail: hprbrazil@hotmail.com, hamilton.pozo@anhembimorumbi.edu.br

Getulio Kazue Akabane Centro Estadual de Educação Tecnológica Paula Souza, Brazil. E-mail: getulio@akabane.adm.br

Antonio Cesar Galhardi Centro Estadual de Educação Tecnológica Paula Souza, Brazil. E-mail: prof.galhardi@fatecjd.edu.br

Helena Gemignani Peterossi Centro Estadual de Educação Tecnológica Paula Souza, Brazil.

E-mail: hgemig@bol.com.br

Submission: 16/01/2015

Revision: 29/01/2015

Accept: 01/02/2015

\section{ABSTRACT}

This paper analyses cases from the automotive industry, mainly green supply chain management aspects of three case examples of decisions in green practices in supply chain design in the automotive industry. Since the 1990s, environmental issues have put companies under a growing pressure to reduce their environmental impact, especially in logistics operations. As a result, green supply chains have been gaining importance on the agendas of business executives seeking to create competitive distinction. Many companies have adopted a "green attitude," seeking ways to integrate environmental dimensions into their business. The methodology used was a Survey with questions were based on patterns in green initiatives in the literature, this study's sample was three large assembly companies in the automotive segment, with industrial plants located both in the 
southeast region of Brazil and globally. The results show that the wave of sustainability is a result of more than just the threat of negative publicity, and it is pushing enterprises into the green zone. At the same time, economic instability with oscillating growth is forcing enterprises to concentrate on improving efficiency to compensate for unstable demand and the price volatility of commodities, including water and energy.

Keywords: green logistics, sustainability, services supply chain management, car manufacturing.

\section{INTRODUCTION}

Enterprises in the twenty-first century face a world that is changing constantly. In this context, Mollenkopf, Stolze, Tate, and Ueltschy (2010) observed three trends in supply chains that converge to create more and more complex business environments: globalization of operations, adoption of lean processes, and moves towards green operations. They pointed out that globalization has made increased revenues possible, as entry into new markets means access to new supplier channels to obtain raw materials at competitive costs and more efficiently than from domestic sources. They also pointed out the growing tendency of enterprises to move their operations from their host countries to geographical regions that provide cost reduction, especially in manufacturing.

Global supply chains introduce additional dimensions such as production outsourcing, infrastructure, inventories, suppliers, customers, cultures, regional economic differences, currencies, and competitive environment policies (MANUJ; MENTZER, 2008; SCHMIDT; WILHELM, 2000; CHRISTOPHER, 2005).

Currently, lean supply chain strategies concentrate on waste reduction, supporting enterprises in eliminating elements that do not add value, such as excessive time, tasks, equipment, spaces, and inventories along supply chains (CORBETT; KLASSEN, 2006). These strategies allow enterprises to improve operational quality, as well as reducing costs and improving their level of custom service - to minimize traditional lot sizes and lines in mass production processes and consequently transform supply chain structures (LARSON; GREENWOOD, 2004). Lean practices are becoming more and more difficult to implement and support due to the growing extent and complexity of supply chains. 
Green supply chain (GSC) strategies refer to enterprises' efforts to minimize the negative impact of supply chains on natural environments. Addressing questions of climatic changes, pollution, and constraints such as non-renewable resources, enterprises are paying attention to stakeholders' demands for corporative citizenship behavior and superior performance (SARKIS, 2001; DE BURGOS JIMENEZ; CESPEDES LORENTE, 2001). The focus of green supply chains encourage working closely with suppliers and clients, analyzing operations and internal processes, paying attention to environmental issues during product development, and extending management of products' life cycles (CORBETT; KLASSEN, 2006; MOLLENKOPF, 2006).

While there are different research groups related to green, lean, and global subjects, few authors pay attention in the intersection of these strategic initiatives (see Figure 1). This question identifies a gap in the literature because enterprises can lose their synergies during the implementation of simultaneous improvements and they do not get important information during incidents of incompatibility between these strategic initiatives. For example, lean and green strategies quite often are seen as compatible initiatives because of their joint focus on waste reduction. Although recently there has been a substantial growth of academic articles that explore practices of GSC management, these still require translation by specialists into how, how many, and which companies can translate these strategic intentions into GSCM practices.

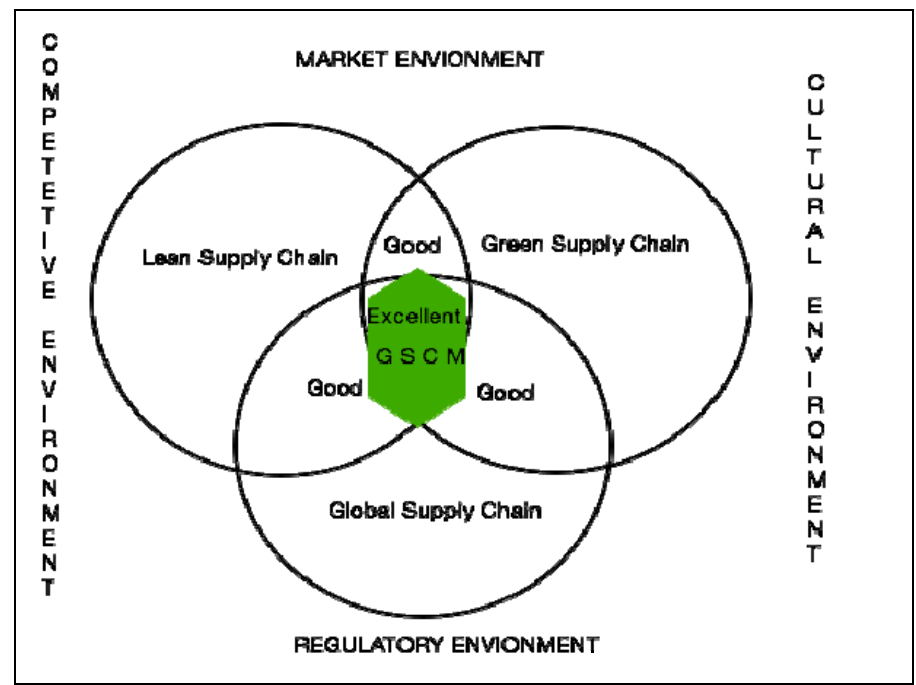

Figure 1: Research domain of green, lean, and global supply chains Source: Mollenkopf et al. (2010, p. 16) 
DOI: 10.14807/ijmp.v6i2.290

\section{LITERATURE REVIEW}

The questions that surround the future of humanity were clearly outlined in a report published by the United Nations in 1987, in which the term "sustainability" was defined. According to Ittmann (2010), it originates from the Latin word sustenere (tenere: to maintain; sus: on top of). Dictionaries give other meanings for "support," principally "maintaining," "supporting," or "lasting." After the term sustainability was used in the United Nations's report to identify human sustainability on this planet, this definition was enlarged upon by the Brundtland Commission (1987) of the United Nations to include that "sustainable development is development that attends present necessities of the without compromising the capacity of future generations in attending their own necessities."

Nevertheless, from the 1990s onward, environmental issues put companies under growing pressure to reduce their environmental impact, especially in logistics operations. The negative effects of the distribution of goods can damage air quality, generate noise and vibrations, because traffic jams and accidents, and significantly contribute to global warming. The greenhouse effect provokes climate change more strongly than was imagined in early researches (ITTMANN, 2010). It is predicted that transportation of goods in general contributes approximately $8 \%$ of total $\mathrm{CO}_{2}$ (carbon dioxide) global emissions (KAHN RIBEIRO; KOBAYASHI, 2007), so the long-term mission of "sustainable" logistics is the effective reduction of carbon particle emissions in the atmosphere.

For some time now, these effects have been monitored, and new management standards have been introduced. For example, the standards for emissions of stress-resistant diesel engines, known as Euro standards of emission, were developed based on emission projections determined for a calendar of introducing standards, as shown in the chart below (see Table 1). These were to be followed by transport companies with heavy vehicles that have a significant environmental impact (ITTMANN, 2010).

In fact, most global companies are expanding their efforts to integrate environmental dimensions into their business (CARBONE; MOATTI, 2008). Several studies in the literatures on GSC examined the importance of working through the supply chain with customers and suppliers through environmental initiatives that 
DOI: $10.14807 /$ ijmp.v6i2.290

produce general performance improvement in enterprises (VACHON; KLASSEN, 2006b). These initiatives develop the capacity to share knowledge (VACHON; KLASSEN, 2008) and add resources to obtain competitive sustainable advantages from environmental programs.

Table 1: Emission standards for stress-resistant diesel engines, in grams per kilowatt-hour

\begin{tabular}{|l|l|l|l|l|l|}
\hline Tier & $\begin{array}{l}\text { Date of } \\
\text { Implementation }\end{array}$ & CO & HC & NO & PM \\
\hline Euro I & $1992(>85 \mathrm{kw})$ & 4.5 & 1.1 & 8.0 & 0.36 \\
\hline Euro II & 1998 & 4.0 & 1.1 & 7.0 & 0.15 \\
\hline Euro III & 2000 & 2.1 & 0.66 & 5.0 & 0.10 \\
\hline Euro IV & 2005 & 1.5 & 0.46 & 3.5 & 0.02 \\
\hline Euro V & 2008 & 1.5 & 0.46 & 2.0 & 0.02 \\
\hline Euro VI & 2013 & 1.5 & 0.13 & 0.4 & 0.01 \\
\hline
\end{tabular}

Source: www.nao.org.uk $(2010)^{1}$

Enterprises are re-structuring their supply chains to operate on a global basis, obtaining advantages through international products, in operational factors and capital markets (MANUJ; MENTZER, 2008, p. 133). Nevertheless, the management of global supply chains presents several challenges, including important aspects of economic and cultural environments, as well as regulations. Global supply chains accent the importance of managing risk (MANUJ; MENTZER, 2008).

In spite of these efforts to increase sustainability, quite often companies suffer from a reduced and fragmented vision based on an illusion of improvements in punctual practices in each section of supply chains, which becomes an obstacle to understanding that sustainable supply chains can add up to more than just meeting obligations, reducing costs, or supporting charities. Therefore, specific sustainable activities identified as having a better fit in different contexts (e.g., types of products, demand characteristics, and social issues) can be beneficial if companies recognize sustainable supply chains will become a source of competitive advantage and leverage to reduce environmental effects.

\footnotetext{
${ }^{1}$ Note. ${ }^{1}$ CO: carbon monoxide ${ }^{2} \mathrm{HC}$ : hydrocarbon ${ }^{3} \mathrm{NO}$ : nitrogen oxide ${ }^{4} \mathrm{PM}$ : particles per
} million 
In this way, GSC has assumed increasing importance in business executives' agendas. Many companies have adopted a "green attitude," claiming an interest in integrating environmental dimensions in their business.

In terms of academic literature, the number of publications on GSC has increased (SRIVASTARA, 2007), accompanied by extensive literature reviews. Several articles (BEAMAN, 1999; HOFFMAN, 2007; PARRY; MARTHA; GRENON, 2007) have discussed the importance of GSCs and the urgent necessity of implementing these into business. In addition, many authors have explored environmental initiatives in isolated formats within each link of supply chains, focusing predominantly on one functional area (SARKIS, 1999).

The contributions of Rao and Holt (2005) included entire supply chains, recognizing that critical steps of sustainable principles of integration in operational contexts require interaction between sustainability (or environmental principles) and supply chains (LINTON; KLASSEN; JAYARAMAN, 2007) and, consequently, GSCs that permeate each stage of manufacturing processes.

Therefore, the main logistics objective is to coordinate activities in order to meet customers' needs and demands at a reduced cost. In the past, cost factors were defined in purely monetary terms. With the growth of environmental issues, companies now pay attention to logistics costs associated mainly with climatic change, air pollution, noise levels, vibration, and accidents caused by movements of goods and services.

In this way, green logistics are defined as "efforts in reducing appearances and obtaining a more sustainable balance between economic, environmental, and social objectives [. . .], where all efforts in the field of 'green' logistics are focused on the contributions that secure the sustainability of the planet" (ITTMANN, 2010).

\subsection{Global Supply Chain}

Researches in the academic and applied literature on environmental management in supply chains indicate that enterprises have included GSCs in operations. This is done especially in order to deal with legal issues and regulations, stakeholders' demands, the risk of loss of reputation, the search for competitive advantage, customers' demands, and pressure from environmental groups (BOWEN et al., 2002; PREUSS, 2001; RAO, 2002; ROBERTS, 2003; SARKIS, 2001). 
The GSC concept arose as green purchasing was integrated into closed-loop supply chains (HERVANI; HELMS; SARKIS, 2005), and, subsequently, it was enlarged to include green solutions with the addition of green purchasing, green manufacturing, green marketing and distribution, and reverse logistics (BACALLAN, 2000, p. 18).

Several authors published papers on studies examining the proximity between practices of green and lean operations, many ways to improve these, and possible performance measures (FLOWERY, 1996; KLASSEN, 2001; BOWEN et al., 2002). These authors pointed out that lean production successes in the field of sustainability emanate from three main factors: the reduction to a minimum of activities that do not add value, the adoption of efficient job systems, and best practices of human resources management.

GSC management is best defined as "environmental management alignment and integration inside of supply chain management" (KLASSEN; JOHNSON, 2004). The research clearly recognizes that enterprises' environmental impact spreads outside their boundaries. In addition, definitions include product design, all manufacturing steps, distribution, and all aspects of reverse logistics (see Figure 2).

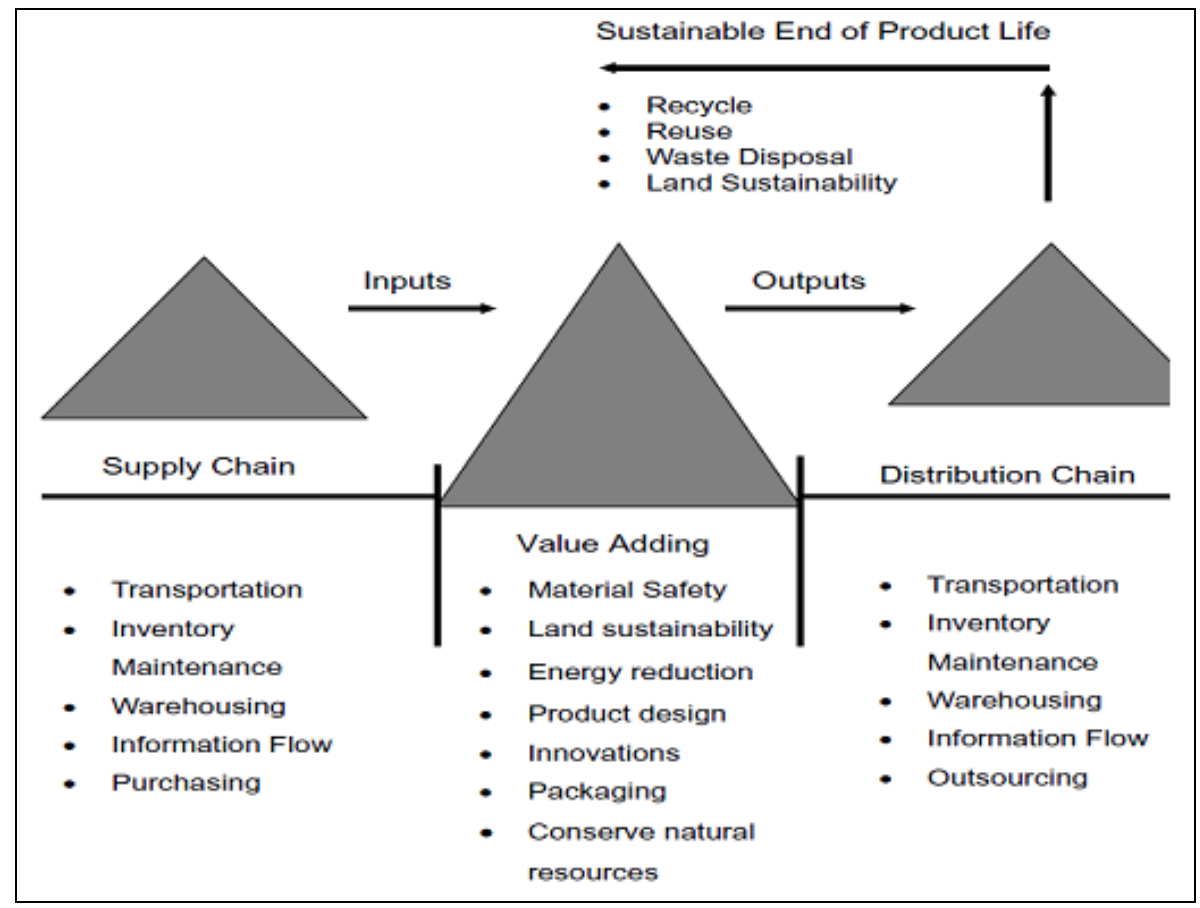

Figure 2: Characteristics of sustainable supply chains Source: www.greenlogistics.org (2011) 
Srivastara (2007) conceived of GSC management (GSCM) as "integrated environmental thinking of supply chains including product design, procurement and materials choice, manufacturing processes, product delivery to the consumers and the end of product life cycle after use." Likewise, as argued in the literature on strategic management (PORTER; KRAMER, 2006) and supply chains (BOWEN et al., 2002), the connection between sustainable behavior and competitive advantage is important in different contexts.

The growing phenomenon of the reallocation of production plants to regions with lower costs in land and labor, as well as other advantages given through incentives, has also become a topic in the literature on outsourcing green manufacturing (TROWBRIDGE, 2003). In GSCs' upstream, green logistics includes all connections with suppliers and manufacturers, all the way up to end users, including products, processes, packaging, transport, and waste disposal at the consumption point (SKJOETT-LARSEN, 2000).

According to Murphy, Poist, and Braunschweig (1996), green logistics principally investigates environmental issues in logistics operations. Murphy and Poist (2000) further explained that green logistics strategies include recycling processes and reuse of materials, as well as reduction of consumption of raw materials in manufacture processes. As a result of this perspective, closed-loop supply chains have received most of the attention in specialized literature (ROGERS et al., 2002). Authors also point out that pioneers concentrated their researches on reverse logistics. Subsequently, they enlarged gradually into business processes with the integration of all links, from procurement of finished goods up to remarketing of refurbished products (GUIDE; VAN WASSENHOVE, 2001).

Furthermore, researchers have shifted their focus from cost reduction in search of value creation to business processes (KLEINDORFER; SYNGHAL; VAN WASSENHOVE, 2005). They have strengthened their arguments for integrating sustainability factors in processes and flows that place top priority on a core of supply chain management involving product design and manufacture and product cycle extension, among others (LINTON et al., 2007). The product design stage is more and more integrated into GSCs, since around $80 \%$ of the environmental load and even product costs are structured during this phase (REBITZER, 2002). 
The life cycle concept is a dominant instrument of project evaluation that appeared in the middle of the 1970s (HUNT; FRANKLIN, 1996). The life cycle evaluation process includes investigation and evaluation of the environmental impact of products and/or services, which are caused by use or products' entire life cycle. The process stretches out to include all supply chain links and represents an evolution of environmental issues concentrated overall on specific impact analyses of each enterprise belonging to supply chains (BUSHES; HALL, 2007).

In upstream areas, green purchasing can address issues such as production waste reduction, changes to alternative materials with low environmental impact from raw material suppliers, minimization of hazardous materials disposal, and reduction of pollutants emissions. Supplier management is crucial to implementing a green acquisition strategy (SIMPSON; POWER, 2005), and many world-class companies frequently carry out initiatives in order to meet the demands of their socioenvironmental responsibilities (BACALLAN, 2000).

Suppliers' integration into environmental management processes continues to be a core issue in the literature. Findings indicate the rise of three common practices: evaluating suppliers for their environmental performance ( $\mathrm{NOCl}, 2000$; BOWEN et al., 2002), mentoring through supporting and training suppliers (HINES; JOHNS, 2001; BOWEN et al., 2002), and seeking ISO 14000 or similar certification (CHEN, 2005).

A production perspective has characterized most of the literature surveyed, which includes environmental issues in operations. Frosch and Gallopoulos (1989) explored the concept of industrial ecology, suggesting clean production, projects focused on the environment, lean production, and product remanufacture based on reverse logistics.

Some scholars have sought to examine other behavioral components in GSCs, in which more environmentally conscious business performance empowers long-term inter-organizational collaboration (VACHON; KLASSEN, 2008; YOUNG, 2000). They further find that, in addition to other benefits discussed in the literature on GSCs, researches' findings can be classified into three broad groups: benefits to enterprises, processes that involve supply chains, and societies' perceptions regarding the gap between the "high hopes" of green initiatives and, in practice, slow 
DOI: 10.14807/ijmp.v6i2.290

implementation of green concepts in enterprises' supply chains. The latter gap calls for additional exploratory surveys of GSCs, redirecting efforts from theory to commercial practices, since only businesses can undertake initiatives and results can only appear with such practices.

Bowen et al. (2002) examined green supply practices in the United Kingdom and identified three types of GSC initiatives, which present different levels of practical results. They found a connection between GSC patterns and corporate environmental objectives.

Rao (2002) showed through empirical investigation carried out in southeast Asian that pressure from customers constitutes the main factor that companies take into consideration when implementing a GSC. De Brito, Carbone and Meunier (2008) discussed the impact of sustainable supply chain initiatives in European textile clothing chains, concluding that legislation is the biggest stimulus behind the implementation of green concepts.

\subsection{Environmental Impact Evaluation Model}

Developed by Albino, Izzo, and Kuhtz (2002), this model is a useful instrument for global enterprises to evaluate the environmental impact of production processes in supply chains. The measurement of performance in GSCM is discussed by Hervani et al. (2005) and Clift (2003); nevertheless, there is little mention of measures that enterprises could adopt to evaluate their carbon footprint in a global context.

One of the most common global benchmarks for environmental initiatives is ISO 14000 certification from the International Organization for Standardization, which requires a series of proceedings to identify environmental aspects of onsite operations, safe handling and procedures for hazardous waste material processing, and compliance with relevant environmental legislation. The ISO 14000 certificate is most commonly adopted by multinational enterprises, which stimulates their suppliers to be certified. Quite often, ISO 14000 standards are also incorporated in supplier selection processes (CHEN, 2005; MILES; MUNILLA; MCCLURG, 1999).

Lean processes create value by eliminating waste in supply chains (DISNEY; NAIM; TOWILL, 1997), including production of goods still not ordered, reduction of waiting time, error correction, elimination of excess in processes and movements, 
DOI: $10.14807 /$ ijmp.v6i2.290

and cutbacks in unnecessary stock and transport (JONES; HINES, 1997). The literature on lean supply chains emphasizes administrations' application of lean practices (MANRODT; VITAZEK; THOMPSON, 2008), the integration of lean and agile operations (MASON-JONES; NAYLOR; TOWILL, 2000; GOLDSBY; GRIFFIS; ROATH, 2006), and concentration on the specific functional areas of supply chains, including lean logistics (DISNEY; NAIM; TOWILL, 1997). Due to the widespread acceptance of lean supply chain practices and growing pressure for environmental management, enterprises have begun to incorporate environmentally friendly practices in waste reduction programs.

Other literature has examined the environmental impact of commerce (FRANKEL; ROSE, 2005; ZENG; EASTIN, 2007) and the connection between green and global supply chain practices and enterprise performance (ZHU; SARKIS, 2004; RAO, 2002). Nevertheless, international researches tend toward local environmental problems and neglect global supply chains.

Several factors cause enterprises to pursue GSC practices in a global context. These include global environmental standards such as ISO 14000 (RAPPAPORT; FLAHERTY, 1992; RONDINELLI; BERRY, 2000; UNCTAD, 1993; EPSTEIN; ROY, 1998; MILES; RUSSELL, 1997), headquarter policies (HANSEN; MELNYK; CALANTONE, 2004), effects of environmental performance on enterprises' global reputations (CHRISTMANN, 1998), reduction of cost (ZHU; SARKIS; GENG, 2005; CRUSH et al., 2008; DOWELL; HART; YEUNG, 2000; CHRISTMANN; TAYLOR, 2001), and pressures from stakeholders and competitors (ZHU at al., 2008; CHRISTMANN; TAYLOR, 2001; MAXWELL et al., 1997; WALKER; DI SISTO; MCBAIN, 2008).

The existing barriers include suppliers' resistance (Wycherley, 1999; Walker et al., 2008), lack of benchmarks and data available with which to measure green practices along global supply chains (VELEVA et al., 2003), and risk and opportunity costs through the loss of key partners in GSCs (ZHU; CORRAL, 2004). These barriers have been identified through case studies and interviews (WYCHERLEY, 1999; WALKER et al., 2008), anecdotal evidence (VELEVA et al., 2003), and researches on a wide range of Chinese manufacturing facilities' managers (ZHU; SARKIS, 2004). 
Paper seeks to determine "how companies formulate their green initiatives and to analyze the logistical bases and results connected with such decisions" but methodology used in this paper is insufficient. It also does not point out the most important factors that have been included in Survey.

\section{RESEARCH METHODOLOGY}

Along the same line of inquiry, the present research sought to illustrate green practices in each section of supply chains, to deepen the discernment of ways in which companies translate their green directives and to analyze the logistical basis and connected results of such decisions. To determine the nature of the above presented issues, an initial bibliographical review (i.e., desk research) was carried out of relevant sources found in books, theses, journals, and articles in specialized magazines. The sample included three international companies in the automotive segment, with industrial plants located in the southeast and south regions of Brazil, in the state of Sao Paulo.

The companies were evaluated using a questionnaire with 40 variables. Each variable came with five options; each attributed a weight from one to five on a Likert scale, where one represented precarious sustainability conditions and five, a maximum of sustainable adaptation.

The criterion for choosing these companies was non-probability sampling, which according to Mattar (1996, p. 132) is when the "selection of elements of the population to compose samples depends at least in part on the researcher or interviewer's judgment in the field." In other words, sampling was carried out in accordance with the researchers' judgment, so that specialized interviewees answered 40 items in closed questionnaires and wrote remarks on items if necessary.

Kish (1965), Aaker, Kumar, and Day (1995), and Kinnear and Taylor (1979) argued that the choice of experts (i.e., specialized professionals) requires judgment or an intentionally guided form of sampling used to choose "typical" and "representative" samples, which can be useful when it includes a small number of sampled units. In this case study, judgment-based sampling was more trustworthy and representative than probability sampling. 
The survey was formulated to preserve a multinational perspective in terms of geographical initiatives and diversified industrial installations. The questions were based on patterns in green initiatives in the literature, as presented in the previous section. The questionnaire included, on the one hand, the motivations and results expected in the formation of GSCs and, on the other hand, clarification of principal initiatives and green measures of each segment of the companies' supply chains.

\section{SURVEY RESULTS}

The results permit a comparison of three large enterprises of the automotive sector in terms of their sustainability efforts. The companies were evaluated using a questionnaire with 40 variables. Each variable came with five options, each attributed a weight from one to five on a Likert scale and the total points obtained by each company based on this e scale shown, with values of 1 (strongly disagree) to 5 (strongly agree). In Table 2 presents the scores for each variable and the percentages obtained using these evaluation tools, in which $100 \%$ means complete adaptation of the best sustainable practices. The source of the company are: Assembler 1 is Germany, Assembler 2 is Japanese and Supplier is American.

Table 2: Comparison of companies

\begin{tabular}{|l|c|c|c|c|c|c|c|c|c|}
\hline \multicolumn{1}{|c|}{ INDICATORS AV } & \multirow{2}{*}{ Ts } & \multicolumn{2}{c|}{ ASSEMBLER 1 } & \multicolumn{2}{c|}{ SUPPLIER } & \multicolumn{2}{c|}{ ASSEMBLER 2 } & AVRG \\
\cline { 5 - 12 } & & & $\mathbf{S}$ & $\%$ & $\mathrm{~S}$ & $\%$ & $\mathrm{~S}$ & $\%$ & $\mathbf{\%}$ \\
\hline 1. GREEN PURCHASE & 10 & 50 & 41 & 82,0 & 28 & 56,0 & 45 & 90,0 & $\mathbf{7 6 , 0}$ \\
\hline 2. GREEN MANUFACTURE & 10 & 50 & 33 & 66.0 & 29 & 58.0 & 40 & 80.0 & $\mathbf{7 4 , 7}$ \\
\hline 3. GREEN PROJECT & 10 & 50 & 39 & 78,0 & 28 & 56,0 & 41 & 82,0 & $\mathbf{7 2 , 0}$ \\
\hline 4. REVERSE LOGISTICS & 10 & 50 & 31 & 62,0 & 34 & 68,0 & 38 & 76,0 & $\mathbf{6 8 , 7}$ \\
\hline AVERAGE GSCM & $\mathbf{4 0}$ & $\mathbf{2 0 0}$ & $\mathbf{1 4 4}$ & $\mathbf{7 2 , 0}$ & $\mathbf{1 1 9}$ & $\mathbf{6 0 , 0}$ & $\mathbf{1 6 4}$ & $\mathbf{8 2 , 0}$ & $\mathbf{7 2 , 8}$ \\
\hline
\end{tabular}

Source: Research data ${ }^{2}$

The companies surveyed are major protagonists in their sector, proactive in respect to the reduction of greenhouse gases and sustainability in a wide sense. The relatively low performance in the economic measurement by the assembly plants reflects the transition through which they are going and restricts, in part, their ability to invest strongly in sustainability projects. It was also observed that the supplier's

${ }^{2} \mathrm{~V}=$ Quantity of variables from the questionnaire; Ts = Total score possible; $\mathrm{S}=$ Score of each company from the questionnaire 
DOI: $10.14807 /$ ijmp.v6i2.290

answers showed eight variables inapplicable to green manufacturing, which inflated its score to $60 \%$.

The samples confirm that these enterprises have been implementing GSC strategies. The Japan-based company is a few steps ahead than Germany company, for example, in its level of consideration of different environmental factors. This Japanese company considers a supply of green raw materials highly important when choosing its partner companies.

Nevertheless, as expected, all three companies are more interested in energy consumption and water processing than in service sectors. Likewise, they put a greater emphasis on employees' health and have decentralized most of their production and distribution. They are currently developing initiatives to reduce transport costs but maintaining sustainability criteria, especially in $\mathrm{CO}_{2}$ emissions.

The data are compared in Figure 3, which shows service percentages for each studied indicator. The level of involvement of suppliers is not as high as expected in relations to automakers and also the level of outsourced enterprises' Involvement is not appropriate in the supply chain and the logistics providers, including bonded warehouses with a more limited dedication to environmental issues as compared to other respondents.

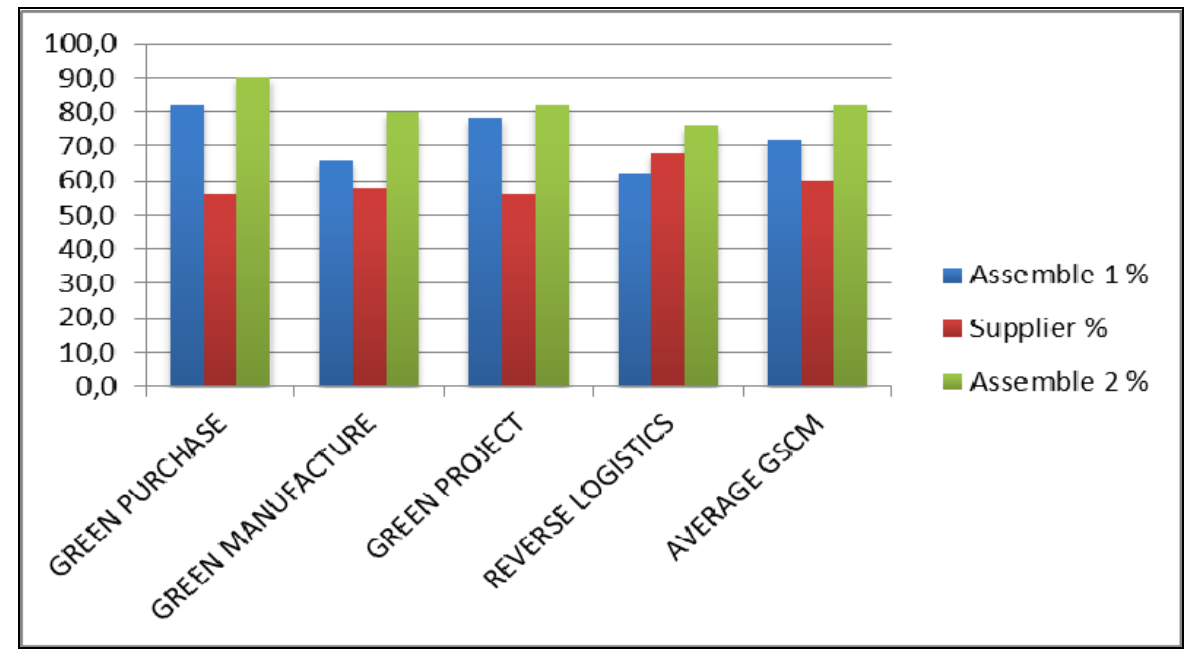

Figure 3: Comparative data

Source: Research data

\subsection{Green Logistics}

The most common environmental measure in the field of green logistics means restructuring logistics flow in order to reduce the number of trips. Since road 
transport is a principal source of greenhouse gas emissions, logistics planning and organization processes that must change to optimize the transportation flow would appear to have high operating leverage. Therefore, it is no surprise that the second most popular method of reducing road transport emissions is to adopt less polluting forms of transport, an approach used in the companies' fleets for at least two years.

Most of the companies are implementing GSC measures through modifications in transportation operations and logistics, including fleet renovation. In terms of green logistics implementation, the companies include logistics flow optimization and company image improvement, as well as logistics cost reduction and landmark regulations. The degree of complexity of such initiatives and high associated costs are the main disincentives observed for environmental damage reduction.

\subsection{Green Purchasing}

Suppliers' involvement is crucial for green projects in which enterprises carry out auditing, as they identify and put into practice key performance indicators to monitor suppliers' green performance. Three principal initiatives have been adopted in eco acquisition strategies, that is, direct purchase of less polluting materials and products, suggestions to suppliers in a continuous process of implementing environmental management systems, and a change in suppliers in order to find those better suited to green acquisitions. Acquisition and manufacturing strategies are functions most affected by environmental issues. Initiatives in product logistics and design show the reverse tendencies in that they receive a low degree of attention from the companies surveyed.

\subsection{Green Manufacturing}

Two main green initiatives in manufacturing refer to production processes' modification, equipment utilization, and less polluting materials. Closely related to these issues is the process of optimization and lean manufacturing concepts of reducing waste during manufacturing operations.

Besides purely environmental considerations, these processes reflect on issues such as manufacturing cost optimization and operations themselves. Because they undertake direct actions in terms of resources and other parts of production, the companies investigated have secured greater efficiency, as opposed to if they used 
more onerous methods at the end of the cycle of production. The initial reasons for adopting green manufacturing is, on the one hand, improved financial performance (i.e., cost reduction through optimization and improvement in resource consumption) and, on the other hand, the ability to follow regulations, including current laws. Only assembly plant 2 (see Figure 3 ) meets these requirements.

\subsection{Green Projects}

In the sample, the enterprises have been implementing eco-design products and/or manufacturing processes. The Japanese company is still some steps ahead in this area according to the data on adopting a green attitude in the product design phase. The survey results show that, in most cases, green design is applied to products or to their components and packaging. In only a small percentage of cases, this approach has been applied to manufacturing processes in order to reduce energy consumption and waste production.

According to the principle of "from cradle to grave," most of the companies have adopted green projects to make more easily recycled products. Based on the data, it can be estimated that most of the enterprises have adopted green designs to improve their brand image, to satisfy stakeholders' demands and increase consumers' confidence.

\subsection{Reverse Logistics}

Most of the companies have adopted reverse logistics for product recovery and refurbishment. Half of the reverse logistics operations involve finished products and packaging. Recovering initiatives for both items refers respectively to refurbishing and recovering, as well as recycling and reuse after cleaning or restoration.

The companies that have decided to establish reverse logistics structures are motivated by the desire to "meet consumer expectations," a reason pointed out by most of the respondents. Reverse logistics is a way for companies to acquire a certain dignity in their market, showing corporative citizenship and reinforcing their positive image and the loyalty of clients and society. The need to respect reverse policies is a third direction that growing numbers of large industries appear to be adopting. 
It is interesting to note that a third of the companies surveyed that have adopted sustainable supply chains believe that reverse logistics structures are not that necessary in their market. The degree of complexity and associated difficulties are the second major disincentives for companies that are using reverse logistics. First, the companies think that reverse logistics is complex because it involves a complete cycle structure from initial stimulations, selective collection, sorting, storage, and recycling in order to send products on to the next phase. The second reason is that several intermediaries are integral to each stage of the cycle, increasing the difficulty to finalize such operations.

\section{FINAL CONSIDERATIONS}

This paper was investigate how GSCM practices in three automotive companies in relation to their practices are and could guide and organize future research in GSCM. First the concepts of GSCM were reviewed by connecting them to the previous concepts of SCM. Subsequently, relevant articles were reviewed which aimed to propose organizations for the theme. Based on the revised structures and keeping in mind the future research possibilities, after it was proposed a framework that can be used as a reference for future research.

Green supply chain decisions can be connected to the performance analysis of supply chains. As multi-criteria decision making is already everyday balancing between cost, lead-time, and on-time delivery, adding environmental sustainability related measures is an obvious next step for companies. The cases presented show that there are several layers of decisions, which can improve the operations, and efficiency of supply chains management. Structural level decisions may be related to products and production

The research showed that automakers have studied a more accurate view of the importance of GSCM showing high factor of performance with Green Purchase (86\% of action); Manufacture Green (74\% of action); Green Project ( $80 \%$ of action) and Reverse Logistics (69\% of action). The supplier proved to be low of automakers with an overall average of $60 \%$ against $78 \%$ of automakers. So, the rated supplier needs to improve their performance in GSCM.

The discussed above justifies continuing present trends in researches, although it will be necessary to enlarge the samples and include other economic 
DOI: 10.14807/ijmp.v6i2.290

segments in addition to those discussed in this paper. On the one hand, there is a need to understand the specific benefits of GSCM. On the other hand, the institutionalization of a "green attitude" deserves renewed exploration.

The planning and integrated management of supply chains recognizes that design must begin with resource extraction and finish with product disposal or renovation. Extensive supplier pre-qualification and evaluation is quite important in order to assure the "right" suppliers are used. It also requires an extensive use of auditing and standards of certification in all steps of supply chains (e.g., ISO 14000), as well as the introduction of return systems for products (i.e., reverse logistics) and sale of waste.

These initiatives reiterate green logistics, where GSCs are sustainable and will become a pre-requisite in the near future. Environmental pressures and debates on subjects such as climatic change are growing, increasing the emphasis given by governments and consumers to these issues and making them truly critical aspects in business management.

\section{REFERENCES}

AAKER, D.; KUMAR, V.; DAY, G. (1995). Marketing research. Hoboken, NJ: John Wiley \& Sons, Inc. 1995.

ALBINO, V.; IZZO, C.; KUHTZ, S. (2002). Input-output models for the analysis of a local/global supply chain, International Journal of Production Economics.

BACALLAN, J. (2000). Greening the supply chain. Business and Environment.

BEAMAN, B. (1999). Designing the green supply chain. Logistics Information Management.

BOWEN, F. E.; COUSINS, P. D.; LAMMING, R. C.; FARUK, A. C. (2001). The role of supply management capabilities in green supply. Production and Operations Management.

BOWEN, F.; COUSINS, P.; LAMMING, R.; FARUK, A. (2002). Horses for courses: Explaining the gap between the theory and practice of green supply. Greener Management International.

BUREAU OF TRANSPORTATION STATISTICS. (2007). Commodity flow survey. Retrieved from

http://www.rita.dot.gov/bts/sites/rita.dot.gov.bts/files/publications/commodity_flow_sur vey/index.html

CARBONE, V.; MOATTI, V. (2008). Greening the supply chain: Preliminary results of a global survey. Supply Chain Forum: An International Journal, v. 9, n. 2.

CHEN, C. (2005). Incorporating green purchasing into the frame of ISO 14000. Journal of Cleaner Production. 
CHRISTMANN, P. (1998). Environmental strategies of multinational chemical companies: Global integration or national responsiveness? (Unpublished paper). The Eerson School at UCLA, University of California Los Angeles, Los Angeles, CA.

CHRISTMANN, P. E.; TAYLOR, G. (2001). Globalization and the environment: Determinants of firm self-regulation in China. Journal of International Business Studies, v. 32, n. 3.

CHRISTOPHER, M. (2005). Logistics and supply chain management: Creating value-adding networks (3rd ed.). Harlow, UK: Pearson Education.

CHRISTOPHER, M.; TOWILL, D. (2001). An integrated model for the design of agile supply chains. International Journal of Physical Distribution \& Logistics Management.

CLIFT, R. (2003). Metrics for supply chain sustainability. Clean Technologies and Environmental Policy, v. 5, n. 3.

COOKE, J. A. (2008). The greening of Whirlpool's supply chain. CSCMP's Supply Chain Quarterly.

CORBETT, C. J.; KLASSEN, R. D. (2006). Extending the horizons: Environmental excellence as key to improving operations. Manufacturing \& Service Operations Management, n. 8.

DE BRITO, M.; CARBONE, V.; MEUNIER, C. (2008). Towards a sustainable fashion retail supply chain in Europe: Organization and performance. International Journal of Production and Economics.

DE BURGOS JIMÉNEZ, J.; CESPEDES LORENTE, J. J. (2001). Environmental performance as an operations objective. International Journal of Operations \& Production Management, n. 21.

DISNEY, S. M.; NAIM, M. M.; TOWILL, D. R. (1997). Dynamic simulation modeling for lean logistics. International Journal of Physical Distribution \& Logistics Management, n. 27.

DOWELL, G.; HART, S.; YEUNG, B. (2000). Do corporate global environmental stewards create or destroy market value? Management Science, n. 46.

EPSTEIN, M.; ROY, M. (1998). Managing corporate environmental performance: A multinational perspective. European Management Journal, n. 16.

FLEISCHMANN, M. (2001). Quantitative models for reverse logistics. Heidelberg, Germany: Springer-Verlag.

FLORIDA, R. (1996). Lean and green: The move to environmentally conscious manufacturing. California Management Review.

FRANKEL, J. A.; ROSE, A. K. (2005). Is trade good or bad for the environment? Sorting out the causality. Review of Economics \& Statistics, v. 87, n. 1.

FROSCH, R.; GALLOPOULOS, N. (1989). Strategies for manufacturing. Scientific American.

GILMORE, D. (2010). How real is the green supply chain? Supply Chain Digest. n. 8. 
GOLDSBY, T. J.; GRIFFIS, S. E.; ROATH, A. S. (2006). Modeling lean, agile, and leagile supply chain strategies. Journal of Business Logistics, v. 27, n. 1.

GOLICIC, S. L.; BOERSTLER, C. N.; ELLRAM, L. M. (2010). "Greening" transportation in the supply chain. MIT Sloan Management Review.

GREEN LOGISTICS. (2011). Research into the sustainability of logistics systems and supply chains. Cardiff, UK: Consortium of UK Universities. GUIDE, V.; VAN WASSENHOVE, L. (2001). Managing product returns for remanufacturing. Production Operations Management.

HANSEN, J. D.; MELNYK, S. A.; CALANTONE, R. (2004). Core values and environmental management: A strong inference approach. Greener Management International, n. 46.

HAVENGA, J. H.; VAN EEDEN, J.; SIMPSON, Z. (2010). The state of logistics in South Africa-Sustainable improvements or continued exposure to risk. In D. King (Ed.), Sixth State of Logistics Survey (p. 14-23). Pretoria, South Africa: CSIR Report.

HERVANI, A.; HELMS, M.; SARKIS, J. (2005). Performance measurement for green supply chain management. Benchmarking: An International Journal.

HINES, F.; JOHNS, R. (2001). Environmental supply chain management:

Evaluating the use of environmental mentoring through supply chain (Unpublished paper). Greening of Industry Network Conference, Bangkok.

HOFFMAN, W. (2007, October). Who's carbon-free? Wal-Mart takes on supply chains of products as expansive carbon measuring plan eyes distribution. Traffic World.

HUNT, R.; FRANKLIN, W. (1996). LCA—How it came about-Personal reflections on the origin and the development of LCA in the USA. International Journal of Life Cycle Assessment.

INSIGHT SURVEY REPORT. (2008). How mature is the green supply chain? Supply Chain Monitor. Vienna: Bearing Point, Inc.

ITTMANN, H. W. (2010). Green supply chains-a new priority for supply chain managers. Pretoria, South Africa: CSIR Built Environment.

JONES, D. T.; HINES, P. (1997). Lean logistics. International Journal of Physical Distribution \& Logistics Management, n. 27.

KAHN RIBEIRO, S.; KOBAYASHI, S. (2007). Transport and its infrastructure. In: METZ, B.; DAVIDSON, O. R. ; BOSCH, P. R.; DAVE, R.; MEYER, L. A. (Eds.), Fourth assessment report: Climate change 2007-mitigation of climate change (Chapter five). Geneva: Inter-Government Panel on Climate Change.

KISH, L. (1965). Survey sampling. Hoboken, NJ: John Wiley \& Sons, Inc.

KLASSEN, R. (2001). Plant-level environmental management orientation: The influence of management views and plant characteristics. Production and Operations Management.

KLASSEN, R. D.; JOHNSON, F. (2004). The green supply chain. In S. J. New \& R. Westbrook (Eds.), Understanding supply chains: Concepts, critiques and futures ( $p$. 229-251). Oxford: Oxford University Press. 
KLEINDORFER, P.; SYNGHAL, K.; VAN WASSENHOVE, L. (2005). Sustainable operations management. Production and Operations Management.

LARSON, T.; GREENWOOD, R. (2004). Perfect complements: Synergies between lean production and eco-sustainability initiatives. Environmental Quality Management, n. 13.

LINTON, J.; KLASSEN, R.; JAYARAMAN, V. (2007). Sustainable supply chains: An introduction. Journal of Operations Management.

MANRODT, K. B.; VITASEK, K.; THOMPSON, R. (2008). Putting lean to work. Logistics Management.

MANUJ, I.; MENTZER, J. T. (2008). Global supply chain risk management. Journal of Business Logistics, v. 29, n. 1.

MASON-JONES, R.; NAYLOR, B.; TOWILL, D. (2000). Lean, agile or leagile? Matching your supply chain to the marketplace. International Journal of Production Research, v. 38, n. 17.

MATOS, S.; HALL, J. (2007). Integrating sustainable development in the supply chain: The case of life cycle assessment in oil and gas and agricultural biotechnology. Journal of Operations Management.

MATTAR, F. (1996). Pesquisa de marketing. Sao Paulo, Brazil: Editora Atlas. MAXWELL, J.; ROTHENBERG, S.; BRISCOE, F.; MARCUS, A. (1997). Green schemes: Corporate environmental strategies and their implementation. California Management Review.

MCKINNON, A. (2010). Environmental sustainability: A new priority for logistics managers. In: MCKINNON, A. et al. (Eds.), Green logistics: Improving the environmental sustainability of logistics (p. 31-48). London: Kogan.

MELNYK, S. A.; DAVIS, E. W.; SPEKMAN, R. E.; SEOR, J. (2010). Outcome-driven supply chains. MIT Sloan Management Review.

MILES, M.; RUSSELL, G. (1997). ISO 14000 total quality environmental management: The integration of environmental marketing, total quality management, and corporate environmental policy. Journal of Quality Management, v. 2, n. 1.

MILES, M. P.; MUNILLA, L. S.; MCCLURG, T. (1999). The impact of ISO 14000 environmental management standards on small and medium sized enterprises.

Journal of Quality Management, v. 4, n. 1.

MOLLENKOPF, D.; STOLZE, H.; TATE, W. L.; UELTSCHY, M. (2010). Green, lean, and global supply chains. International Journal of Physical Distribution \& Logistics Management, v. 40, n. 1/2.

MURPHY, P.; POIST, R. (2000). Green logistics strategies: An analysis of usage patterns. Transportation Journal.

MURPHY, P.; POIST, R.; BRAUNSCHWEIG, C. (1996). Green logistics:

Comparative views of environmental progressives, moderates, and conservatives. Journal of Business Logistics.

NOCl, G. (2000). Environmental reporting in Italy: Current practices and future developments. Business Strategy and the Environment. 
PARRY, P.; MARTHA, J.; GRENON, G. (2007). The energy efficient supply chain. Strategy+Business.

PORTER, M.; KRAMER, M. (2006, December). Strategy and society. Harvard Business Review.

PREUSS, L. (2001). In dirty chains? Purchasing and greener manufacturing. Journal of Business Ethics.

RAPPAPORT, A.; FLAHERTY, M. F. (1992). Corporate responses to environmental challenges: Initiatives by multinational management. New York, NY: Quorum Books.

RAO, P. (2002). Greening the supply chain: A new initiative in South East Asia. International Journal of Operations \& Production Management.

RAO, P.; HOLT, D. (2005). Do green supply chains lead to competitiveness and economic performance? International Journal of Operations and Production Management.

REBITZER, G. (2002). Integrating life cycle costing and life cycle assessment for managing costs and environmental impacts in supply chain analysis and LCA. In: SEURING, S.; GOLDBACH, M. (Eds.), Cost management in supply chains.

ROBERTS, S. (2003). Supply chain specific? Understating the patchy success of ethical sourcing initiatives. Journal of Business Ethics, v. 44, n. 2/3.

ROGERS, D.; LAMBERT, D.; CROXTON, K.; GARCIA-DASTUGUE, S. (2002). The returns management process. International Journal of Logistics Management.

RONDINELLI, D. A.; BERRY, M. A. (2000). Environmental citizenship in multinational corporations: Social responsibility and sustainable development. European Management Journal, v. 18, n. 1.

SARKIS, J. (1999). How green is the supply chain? Practice and research. Worcester, MA: Clark University.

SARKIS, J. (2001). Greener manufacturing and operations: From design to delivery and back. Sheffield, UK: Greenleaf Publishing.

SCHMIDT, G.; WILHELM, W. E. (2000). Strategic, tactical, and operational decisions in multi-national logistics networks: A review and discussion of modeling issues.

International Journal of Production Research, v. 38, n. 7.

SCHOEMAN, C.; SANCHEZ-RODRIQUES, V. (2010). Green logistics and sustainability. In KING, D. (Ed.), Sixth State of Logistics Survey (p. 45-51). Pretoria, South Africa: CSIR Report.

SIMPSON, D.; POWER, D. (2005). Use the supply relationship to develop lean and green suppliers. Supply Chain Management: An International Journal.

SRIVASTARA, S. (2007). Green supply-chain management: A state-of-the-art literature review. International Journal of Management Reviews.

TROWBRIDGE, P. (2003). A case study of green supply chain management at advanced micro devices. In: SARKIS, J. (Ed.), Greening the supply chain. London: Springer-Verlag. 
UBEDA, S.; ARCELUS, F. J.; FAULIN, J. (2010). Green logistics at Eroski. A case study. International Journal of Production Economics.

UNCTAD. (1993). Environmental Management in Transnational Corporations: Report on the Benchmark Corporate Environmental Survey. New York, NY: United Nations.

U.S. Environmental Protection Agency. (2007). Inventory of U.S. greenhouse gas emissions and sinks: 1990-2005. Retrieved from http://epa.gov

VACHON, S.; KLASSEN, R. (2008). Environmental management and manufacturing performance: The role of collaboration in the supply chain. International Journal of Production Economics.

VELEVA, V.; HART, M.; GREINER, T.; CRUMBLEY, C. (2003). Indicators for measuring environmental sustainability: A case study of the pharmaceutical industry. Benchmarking: An International Journal, n. 10.

WALKER, H.; DI SISTO, L.; MCBAIN, D. (2008). Drivers and barriers to environmental supply chain management practices: Lessons from the public and private sectors. Journal of Purchasing \& Supply Management, n. 14.

WYCHERLEY, I. (1999). Greening supply chains: The case of the Body Shop International. Business Strategy and the Environment, v. 8, n. 2.

YOUNG, R. (2000). Managing residual disposition: Achieving economy, environmental responsibility, and competitive advantage using the supply chain framework. Journal of Supply Chain Management.

ZENG, K.; EASTIN, J. (2007). International economic integration and environmental protection: The case of China. International Studies Quarterly, v. 51, n. 4.

ZHU, Q.; COTE, R. P. (2004). Integrating green supply chain management into an embryonic eco-industrial development: A case study of the Guitang Group. Journal of Cleaner Production, n. 12.

ZHU, Q.; SARKIS, J. (2004). Relationships between operational practices and performance among early adopters of green supply chain management practices in Chinese manufacturing enterprises. Journal of Operations Management, v. 22, n. 3.

ZHU, Q.; SARKIS, J.; GENG, Y. (2005). Green supply chain management in China: Pressures, practices, and performance. International Journal of Operations \& Production.

ZHU, Q.; SARKIS, J.; CORDEIRO, J. J.; LAI, K.-H. (2008). Firm-level correlates of emergent green supply chain management practices in the Chinese context. Omega, v. 36, n. 4 . 